\title{
PEMANFAATAN LIMBAH JERAMI PADI DI DESA GARON KECAMATAN BALEREJO, KABUPATEN MADIUN
}

\author{
Erry Ika Rhofita ${ }^{1}$, Liliek Chana AW ${ }^{2}$ \\ ${ }^{1}$ Fakultas Sains dan Teknologi, UIN Sunan Ampel Surabaya \\ email: erryikarhofita@uinsby.ac.id \\ ${ }^{2}$ Fakultas Tarbiyah dan Keguruan, UIN Sunan Ampel Surabaya \\ email: liliekchanna@gmail.com
}

\begin{abstract}
Greenhouse gas emissions are an environmental issue that has an impact on climate change and global warming. One of the cause is the burning of rice straw after harvest in the field. The existence of majelis taklim is not only religious facilities, and it's as a way to community empowerment. QS. As-Sad 27 and QS Al-Anbiya 16 explains that everything created by Allah SWT with all aims and benefits. Generally, rice straw is perception as a waste, but if it utilised with science and technology will be able to improve the use of value and economic value. $82,19 \%$ and $79,45 \%$ of the members of majlis taklim have perception that utilizing of rice straw can improve their income and part of the sustainable environmental management. And 94,25\% of the members of majelis taklim did not utilise rice straw and burned it in the field. They did not have skills and knowledge to utilise of the rice straw. Furthermore, training and education must be conducted regularly.
\end{abstract}

Keywords: rice straw; utilization; organic fertilizer

\begin{abstract}
ABSTRAK
Emisi gas rumah kaca menjadi isu lingkungan mengakibatkan perubahan iklim dan pemanasan global. Salah satu penyebabnya adalah pembakaran jerami padi di areal persawahan setelah panen. Keberadaan majelis taklim bukan hanya sebagai sarana keagamaan tetapi sebagai sarana pemberdayaan masyarakat. QS. As-Sad ayat 27 and QS. Al-Anbiya ayat 16 menerangkan bahwa segala sesuatu diciptakan oleh Allah SWT dengan tujuan dan manfaat tertentu. Jerami padi banyak dipersepsikan sebagai limbah, tetapi jika dimanfaatkan dengan ilmu pengetahuan dan teknologi akan meningkatkan nilai guna dan ekonominya. $82,19 \%$ dan $79,45 \%$ anggota majelis taklim berpersepsi memanfaatkan jerami padi dapat meningkatkan penghasilan dan sarana untuk mengelola lingkungan. Dan 94,52\% anggota majelis taklim tidak memanfaatkan dan membakar jerami padi karena tidak mempunyai keterampilan dan pengetahuan untuk memanfaatkannya. Lebih lanjut kegiatan pelatihan harus dilakukan secara berkala.
\end{abstract}

Kata Kunci: jerami padi; pemanfaatan; pupuk organik

\section{PENDAHULUAN}

Permasalahan utama yang dihadapi oleh masyarakat desa adalah pengangguran terselubung. Secara umum jenis penggangguran ini tidak dapat melakukan pekerjaan secara optimal karena jumlah jam kerja dibawah 7 jam perhari dan penghasilan yang berada di bawah Upah Minimum Regional 
(UMR). Salah satu cotoh pengangguran terselubung adalah buruh tani. Beberapa alasan yang mendasari mengapa buruh tani termasuk kedalam jenis pengangguran terselubung, antara lain: 1) tenaga buruh tani hanya diperlukan ketika musim tanam dan musin panen datang; 2) waktu kerja buruh tani tidak lebih dari 7 jam per hari dan hanya berlangsung dalam waktu yang singkat (antara 1-2 minggu); dan 3) upah harian yang diterima jauh dibawah standar UMR kota/kabupaten setempat.

Seperti halnya di Desa Garon, Kecamatan Balerejo, Kabupaten Madiun mayoritas penduduknya $(<60 \%)$ merupakan buruh tani dan termasuk kedalam pengangguran terselubung. Sehingga keberadaan program pemberdayaan menjadi sarana utama untuk meningkatkan sosial ekonomi masyarakat. Pemberdayaan tersebut dapat dilakukan melalui pemanfaatan potensi pertanian seperti limbah jerami padi yang selama ini belum dimanfaatkan secara optimal. Berdasarkan data dari BPS jumlah produksi padi nasional tahun 2016 sebesar 79,14 juta ton meningkat 4,97\% dari produksi padi tahun 2015 dengan besar 75,36 juta ton yang akan menghasilkan limbah jerami padi sebesar 40-50 juta ton pertahun. Adanya peningkatan jumlah produksi padi tersebut akan berdampak pada peningkatan produksi jerami padi nasional yang diperkirakan setiap tahunnya meningkat antara $8-11 \%$. Dengan peningkatan jumlah jerami padi akan berdampak pada meningkatnya jumlah limbah pertanian dan pencemaran lingkungan akibat pembakaran jerami padi tersebut. Selama ini limbah jerami padi hanya dibakar didaerah persawahan dan kurang pemanfaatannya, hal ini dikarenakan sifatnya tersebar diberbagai tempat sehingga berakibat pada mahalnya biaya pengumpulan dan pengankutan/transportasi, (Rhofita, 2016). Pemanfaatan jerami padi hanya sebatas pakan ternak (22\%), pupuk (12\%), dan sisanya dibuang atau dibakar. Pembakaran jerami padi di areal persawahan mampu menurunkan kadar unsur hara tanah seperti nitrogen $(\mathrm{N})$, fosfosr $(\mathrm{P})$, kalium $(\mathrm{K})$, dan sulfur $(\mathrm{S})$ antara 2180\%, (John, 2013; Kanokkanjana, \& Garivait, 2013; M. Z, B, \& Aznie C.R, 2012; Mandal et al., 2004; Muliarta, 2018; Tung, Cu, \& Hai, 2014). Produksi jerami padi yang melimpah dan tersebar diberbagai tempat di Indonesia memungkinkan untuk dimanfaatkan sebagai pakan ternak dan pupuk organik dalam jumlah yang besar. Secara umum komposisi kimia jerami padi meliputi bahan kering 71,2\%; protein kasar 3,9\%; lemak kasar 1,8\%; serat kasar $28,8 \%$; BETN 37,1\% dan TDN 40,2\%.

Berbagai kendala ditemui dalam pemanfaatan jerami padi menjadi pupuk organik salah satunya adalah minimnya SDM dan teknologi pengolahan jerami padi. Hasil observasi awal yang dilakukan di Desa Garon Kecamatan Balerejo Kabupaten Madiun ditemukan beberapa hal penting terkait pemanfaatan jerami padi antara lain: 1) jerami padi di Desa Garon selama ini hanya diletakkan atau dibakar diareal persawahan (Gambar 1); 2) Desa Garon merupakan desa percontohan di Kabupaten Madiun terkait swasembada pangan pada tahun 2015, dan 3) adanya keinginan masyarakat khususnya majelis taklim untuk memanfaatkan jerami padi menjadi barang berdaya guna. 
Berdasarkan hasil observasi awal ini diharapkan melalui pemanfaatan jerami padi menjadi pupuk organik dapat dijadikan sebagai salah satu sarana program pemberdayaan masyarakat khususnya majelis taklim yang ada di Desa Garon. Dengan adanya pengelolaan lingkungan secara berkelanjutan akan berdampak pada keseimbangan lingkungan, seperti halnya dijelaskan dalam Al-Qur'an QS. An-Nahl ayat 5 dan 6, QS. Al A'raaf ayat 56 dan QS. Hud ayat 116.
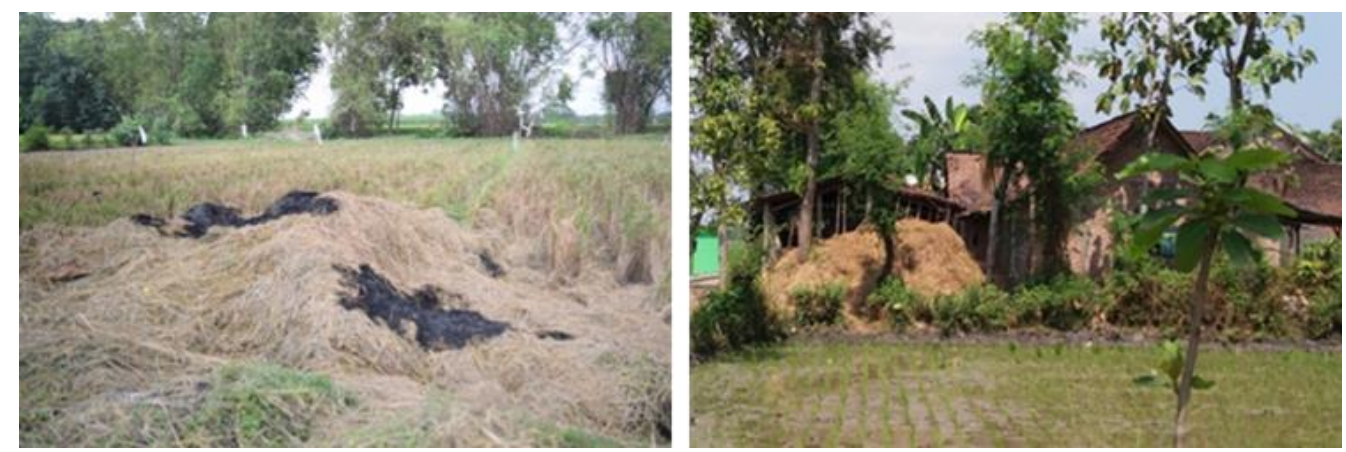

Gambar 1. Kondisi jerami padi di Desa Garon diletakkan diareal persawahan dan dibakar

\section{METODE PELAKSANAAN}

1. Strategi Pelaksanaan Kegiatan

Stategi yang digunakan dalam kegiatan ini dengan menggunakan model yang dikembangkan oleh S. Thagarajan, Dorothy S. Semmel, dan Melvyn I. Semmel (1975), yaitu model pengembangan 4-D yang terdiri atas empat (4) tahap utama yaitu: (1) Define (Pembatasan), (2) Design (Perancangan), (3) Develop (Pengembangan) dan (4) Disseminate (Penyebaran). Melalui metode ini, kegiatan ini dimulai dari proses analisis terhadap wilayah sasaran, kemudian merancang model solusi terhadap masalah yang ada, dilanjutkan proses pengembangan dengan melibatkan stakeholder yang berkepentingan dan kemudian penyebarluasan metode untuk mengukur efektivitas program yang diharapkan mempunyai dampak ganda, yaitu penguatan ekonomi masyarakat melalui pemanfaatan limbah jerami untuk menjadikan pupuk organik dan sekaligus meningkatkan fungsi majlis taklim yang pada mulanya berisi kegiatan keagamaan saja (tahlilan, yasinan dan lainnya) meningkat untuk peduli terhadap kesejahteraan hidup. Atau istilah lainnya dalam majlis taklim tersebut mampu berdakwah bi al-lisan dan dakwah bi al-haq. Dalam kegiatan ini strategi atau pendekatan dilakukan melalui beberapa tahapan dan dijadikan sebagai pedoman pelaksanaan kegiatan (Gambar 2).

a. Mengajak masyarakat melalui kelompok majlis taklim untuk menggali dan menyadarkan pentingnya menjaga keberlanjutan lingkungan khususnya sebagai petani yang modal utamanya adalah persawahan yang harus dijaga kesuburannya; 
b. Pemanfaatan limbah jerami padi karena limbah jerami merupakan asset yang luar biasa, yang masih minim pengelolaannya;

c. Memetakan persepsi dan pemahaman anggota majelis taklim tentang teknologi dan metode pemanfaatan limbah jerami padi untuk diselaraskan dengan kearifan lokal;

d. Memberikan pelatihan-pelatihan yang dianggap perlu;

e. Mengajak masyarakat melalui majlis taklim untuk turun tangan menyelesaikan permasalahan lingkungan dan meningkatkan kesejahteraannya dengan mengolah jerami padi sebagai pupuk organik dengan tetap memperhatikan kelestarian budaya lokal.

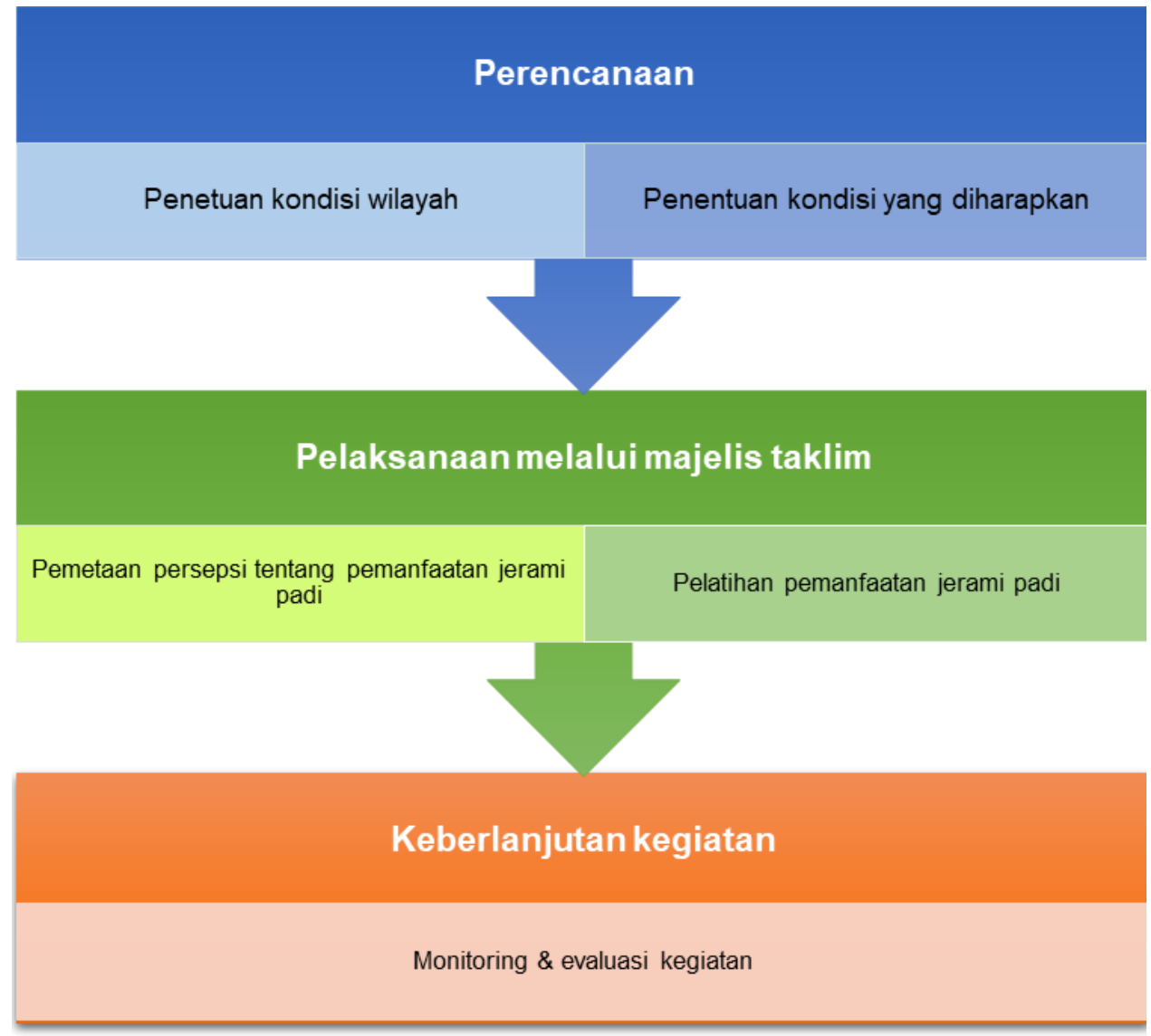

Gambar 2. Tahapan pelaksanaan kegiatan pengabdian kepada masyarakat

\section{Kerangka Konsep Kegiatan}

Kegiatan pengabdian kepada masyarakat berbasis riset secara umum bertujuan memanfaatkan jerami padi sebagai bahan berdaya guna dan menjaga keberlanjutan lingkungan. Sedangkan tujuan akhir kegiatan ini adalah meningkatkan kesejahteraan sosial ekonomi masyarakat. Tujuan 
akhir ini dapat dicapai melalui strategi pelaksanaan kegiatan yang telah dijelaskan dalam sub-bab sebelumnya. Secara terperinci kerangka pemikiran kegiatan ini ditunjukkan oleh Gambar 3.

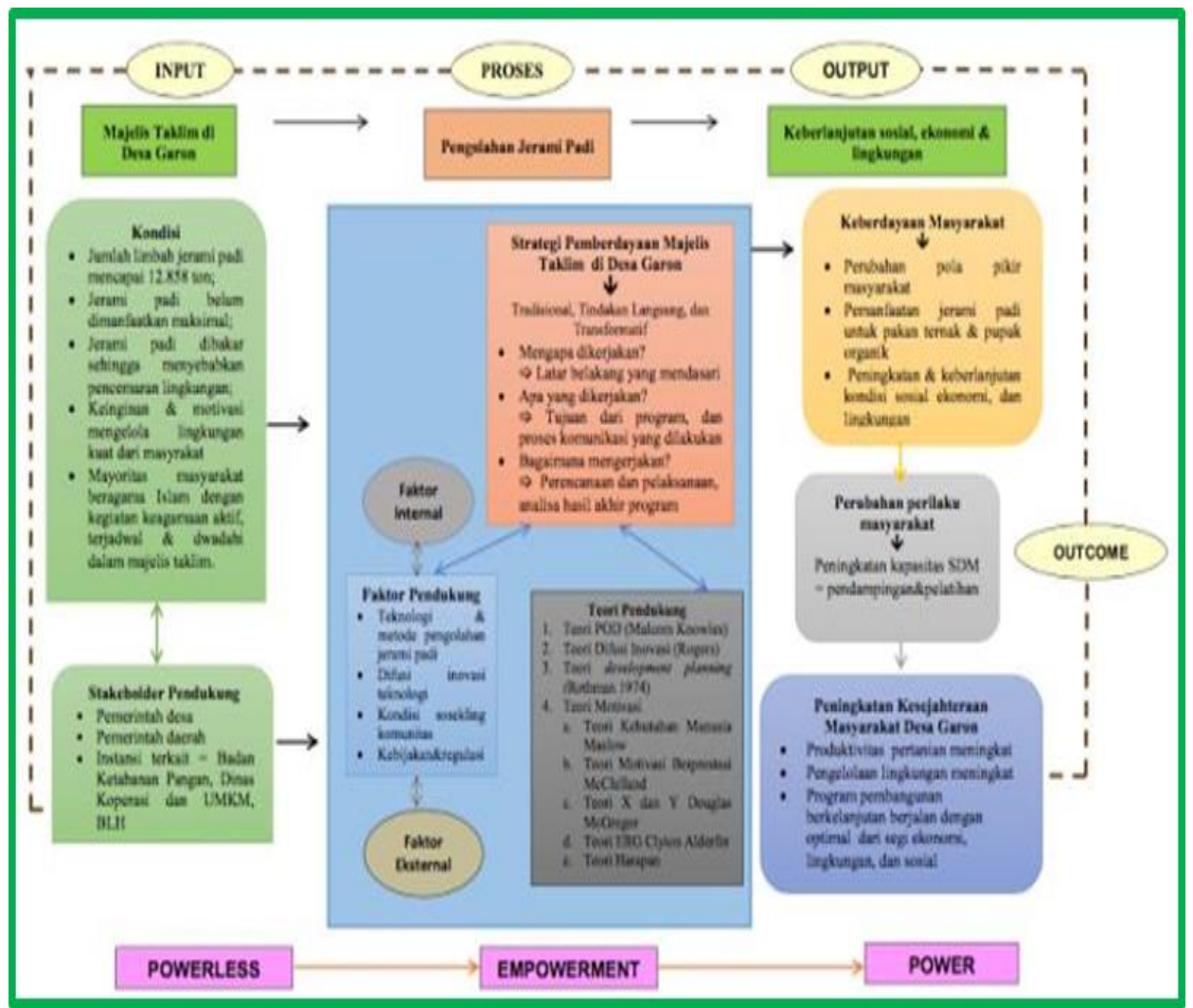

Gambar 3. Kerangka konsep kegiatan pengabdian kepada masyarakat

\section{HASIL DAN PEMBAHASAN}

\section{Kondisi Wilayah Dampingan}

Desa Garon merupakan salah satu desa yang berada dalam wilayah Kecamatan Balerejo, Kabupaten Madiun. Dari segi transportasi mudah untuk ditempuh dengan kendaran apapun termasuk kendaraan umum karena letaknya melewati jalan utama Surabaya - Madiun. Letak \pm 3 $\mathrm{km}$ dari kantor kecamatan Balarejo dan berjarak $\pm 10 \mathrm{~km}$ sebelah timur dari kantor kabupaten Madiun. Secara administratif Desa Garon terbagi menjadi 6 (enam) dusun, yaitu Dusun Kedung Meneng, Dusun Kembangan, Dusun Garon, Dusun Plembang, Dusun Bakung dan Dusun Sumber, dengan 31 RT dan jumlah penduduk sebesar 3099 jiwa yang terdiri dari 1518 orang laki-laki dan 1581 orang perempuan. Luas wilayah Desa Garon $\pm 384,025 \mathrm{Ha}$, peruntukan lahan di desa ini terdiri dari sawah irigasi $78,50 \mathrm{Ha}$; sawah setengan teknis $149,900 \mathrm{Ha}$; sawah tadah hujan 
$17,050 \mathrm{Ha}$; ladang tegalan $84,525 \mathrm{Ha}$; pemukiman $53 \mathrm{Ha}$; tanah untuk pembangunan perkantoran $0,500 \mathrm{Ha}$; tanah untuk bagunan sekolah 0,900 $\mathrm{Ha}$; jalan 4,00 Ha; lapangan 0,500; perikan 0,500 $\mathrm{Ha}$; dan tanah untuk kuburan $4 \mathrm{Ha}$. Adapun batas administratif desa Garon adalah:

- Sebelah Utara : Desa Glonggong, Kecamatan Pilang kenceng

- Sebelah Selatan : Desa Tanjungrejo, Kecamatan Madiun

- Sebelah Barat : Desa Bagi, Kecamatan Madiun

- Sebelah Timur : Desa Balarejo, Kecamatan Balerejo

Secara astronomis, letak koordinat Desa Garon terletak pada titik koordinat $7^{\circ} 42^{\prime} 50,4^{\prime \prime}\left(7,714^{\circ}\right)$ lintang selatan dan $111^{\circ} 24^{\prime} 34,9^{\prime \prime}$ $\left(111,4097^{\circ}\right)$ bujur timur, desa ini juga terletak pada ketinggian rata-rata 134 meter dari permukaan air laut dan sebagian besar wilayahnya tidak termasuk perbukitan dan merupakan lahan pertanian yang luas, sehingga desa ini termasuk wilayah yang sangat subur dan baik untuk bercocok tanam terutama menanam padi dan mayoritas penduduknya berprofesi sebagai petani ( $>65 \%)$.

Dari segi keagamaan, masyarakat tergolong masyarakat berkembang, mayoritas beragama Islam. Masyarakat Desa Garon sama halnya dengan masyarakat lain, yaitu mendirikan masjid dan mushollah sebagai tempat beribadah bagi umat muslim. Masjid dan mushollah bukan hanya memberikan fungsi sebagai tempat beribadah, namun juga berfungsi sebagai tempat mengaji, dan belajar ajaran Islam. Beberapa kegiatan keagamaan yang berlangsung di Desa Garon diantaranya adalah:

a. Jama'ah yasinan

Jama'ah yasinan terdiri dari kelompok ibu-ibu dan bapak-bapak yang dilaksanakan setiap seminggu sekali dan di setiap dusun memiliki jama'ah yasinan. Di dusun Kedung Meneng ada jama'ah yasinan Kedung Meneng yang dilaksanakan setiap hari Kamis malam Jum'at, Dusun Kembangan terdapat jama'ah Nurul Wabilah, Dusun Garon terdapat jama'ah Nurul Iman, dusun Plembang terdapat jama'ah Ibadur Rahman dan Al-Fattah, dusun Sumber terdapat jama'ah Al-Istiqomah, dan di Dusun Bakung dengan nama majelis yasinan (Gambar 4). Kegiatan yasinan di Desa Garon bukan hanya dilakukan di Masjid tetapi kegiatan ini dilakukan dengan sistem anjangsana (bergantian dirumah warga). Jumlah keseluruhan anggota kegiatan ini di Desa Garon sejumlah 372 orang. 


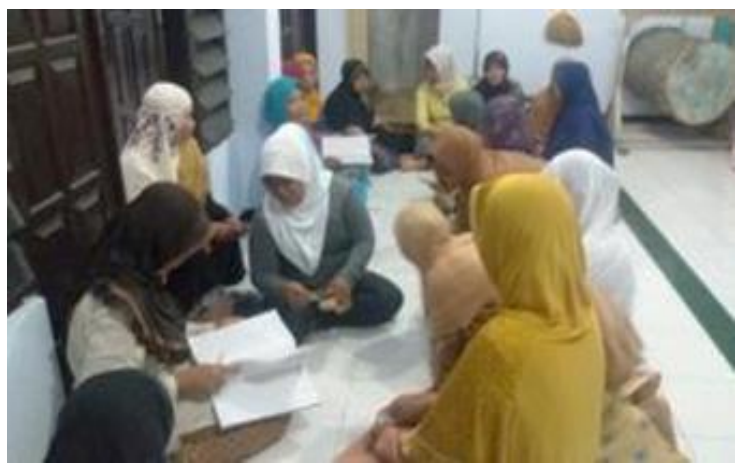

Gambar 4. Kegiatan yasinan di Masjid Al-Fatah, Dusun Kembangan (3 Agustus 2018)

b. Taman Pendidikan Al-Qur'an

Taman pendidikan Al-Qur'an (TPA/TPQ) adalah lembaga atau kelompok masyarakat yang menyelenggarakan pendidikan non-formal jenis kegiatan keagamaan yang bertujuan untuk memberikan pengajaran Al Qur'an, serta memahami dasar-dasar agama Islam. Tidak ada batasan usia dalam belajar Al-Qur'an ini, begitu juga di Desa Garon, tetapi mayoritas siswa di TPQ adalah umur 5 tahun hingga 15 tahun (Gambar 5).
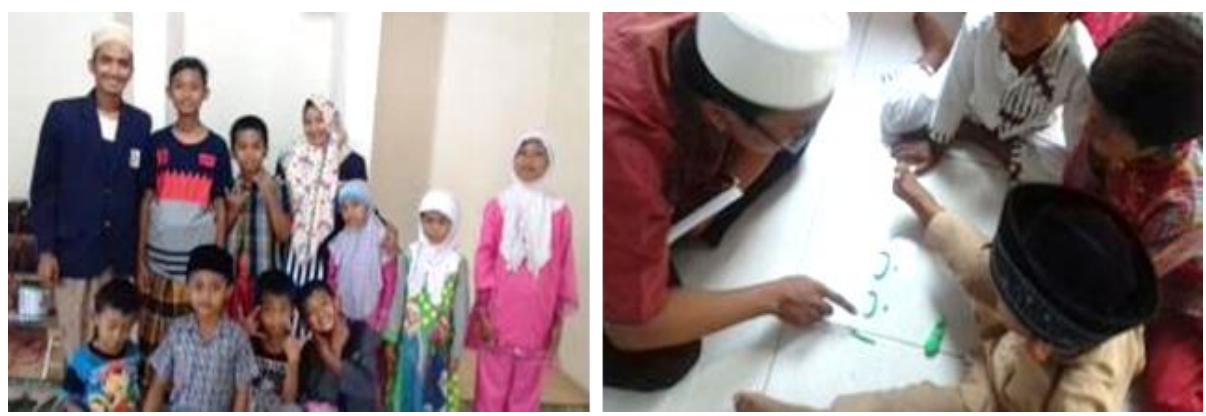

Gambar 5. Kegiatan belajar mengaji TPQ Al-Amin (6 Agustus 2018)

\section{Kondisi yang Diharapkan}

Menurut Dinas Pertanian dan Ketahanan Pangan Kabupaten Madiun, Desa Garon akan dijadikan sebagai sentra penghasil padi terbesar Kabupaten Madiun dan telah menjadi desa percontohan nasional dalam swasembada padi pada tahun 2015. Tingkat pendidikan masyarakat yang rendah (rata-rata berpendidikan SD dan SMP) dan mayoritas bermata pencaharian sebagai petani atau buruh tani diperlukan perhatian khusus dengan memberikan pemahaman dan peningkatan keterampilan dalam mengolah jerami padi. Dari segi ekonomi diharapkan kegiatan ini menjadi sarana kewirausahaan berbasis komunitas yang mampu meningkatkan penghasilan keluarga dan menjadi salah satu produk unggulan dari Desa Garon. 


\section{Persepsi Tentang Pemanfaatan Jerami Padi}

Persepsi tentang pemanfaatan jerami padi dalam kegiatan ini diketahui melalui kuisioner yang diberikan kepada anggota majelis taklim di Desa Garon yang berjumlah 73 orang dengan tingkat kesalahan sebesr $10 \%$. Persepsi ini dimaksudkan untuk mengetahui sejauhmana anggota majelis taklim memanfaatkan jerami padi sebagai bahan berdaya guna dan harapan jika jerami padi tersebut dimanfaatkan (Gambar 6). Keterlibatan anggota majelis taklim dalam mendukung pengelolaan lingkungan yang berkelanjutan ditentukan oleh kemauan mereka dalam memanfaatkan jerami padi menjadi bahan berdaya guna seperti pupuk organik, pakan ternak, bahan baku kerajinan, media penanaman jamur atau bioenergi. Sebanyak 35,62\%; 4,11\%; dan 5,48\% anggota majelis taklim di Desa Garon berturut-turut telah memanfaatkan jerami padi sebagai pakan ternak, pupuk organik dan bahan baku kerajinan serta media penanaman jamur. Sedangkan anggota majelis taklim yang tidak memanfaatkan jerami padi tersebut sebesar $94,52 \%$. Berdasarkan hasil observasi dan wawancara yang telah dilakukan jerami padi hasil sisa panen hanya ditinggalkan areal persawahan dan selanjutnya dibakar jika musim hujan. Sebesar $4,11 \%$ petani beranggapan jika jerami padi ditinggal di areal persawahan akan terdekomposisi secara alami dan berfungsi sebagai pupuk. Jika musim kemarau sebagian jerami dimanfaatkan sebagai pakan ternak dan media penanaman jamur. Pembakaran jerami padi memberikan kontribusi peningkatan emisi gas rumah kaca seperti karbon dioksida (CO2), karbon monoksida (CO), karbon yang terbakar (dengan jumlah jejak metana), nitrogen oksida (NOx), dan jumlah jejak sulfur dioksida (SO2), bersama dengan lainnya partikulat (PM),(Andini, Bonnet, Rousset, \& Hasanudin, 2018; Gadde, Bonnet, Menke, \& Garivait, 2009; Junpen, Pansuk, Kamnoet, Cheewaphongphan, \& Garivait, 2018; Lim, Manan, Wan Alwi, \& Hashim, 2012). Diperkirakan tahun 2030 peningkatan emisi gas rumah kaca dari aktifitas pembakaran biomassa di Indonesia mengalami peningkatan 29\% (Andini et al., 2018).

QS. Al-Baqorah ayat 30 dijelaskan bahwa tugas manusia adalah menjaga dan mengelola lingkungan. Salah satu bentuk kegiatan mengelola lingkungan secara berkelanjutan adalah memanfaatkan jerami padi. Diperkuat dalam QS. As-Sad ayat 27 and QS. Al-Anbiya ayat 16 bahwa Allah SWT menciptakan segala apa yang ada dibumi dan dilangit dengan tujuan dan manfaat. Jerami padi yang selama ini dipandang sebagian orang sebagai limbah jika dimanfaatkan dengan ilmu pengetahuan dan teknologi akan meningkatkan nilai guna dan ekonominya. 82,19\% anggota majelis taklim di Desa Garon berpresepsi dengan memanfaatkan jerami padi dapat memberikan penghasilan tambahan dan sebanyak $79,45 \%$ berpersepsi memanfaatkan jerami padi dapat menjadi sarana untuk mengelola lingkungan dan menjaga keberlanjutan lingkungan. Untuk mendukung kegiatan pemanfaatan jerami padi tersebut, diperlukan 
dukungan dari pemerintah dalam bentuk saran dan prasarana (teknologi dan metode) serta regulasi yang mampu meningkatkan kesadaran, pemahaman dan keberdayaan petani. Hasil observasi dilapangan menunjukkan sebesar $8,22 \%$ anggota majelis taklim mengetahui metode dan teknologi dan $10,56 \%$ pernah mendapatkan penyuluhan dan pelatihan pemanfaatan jerami.

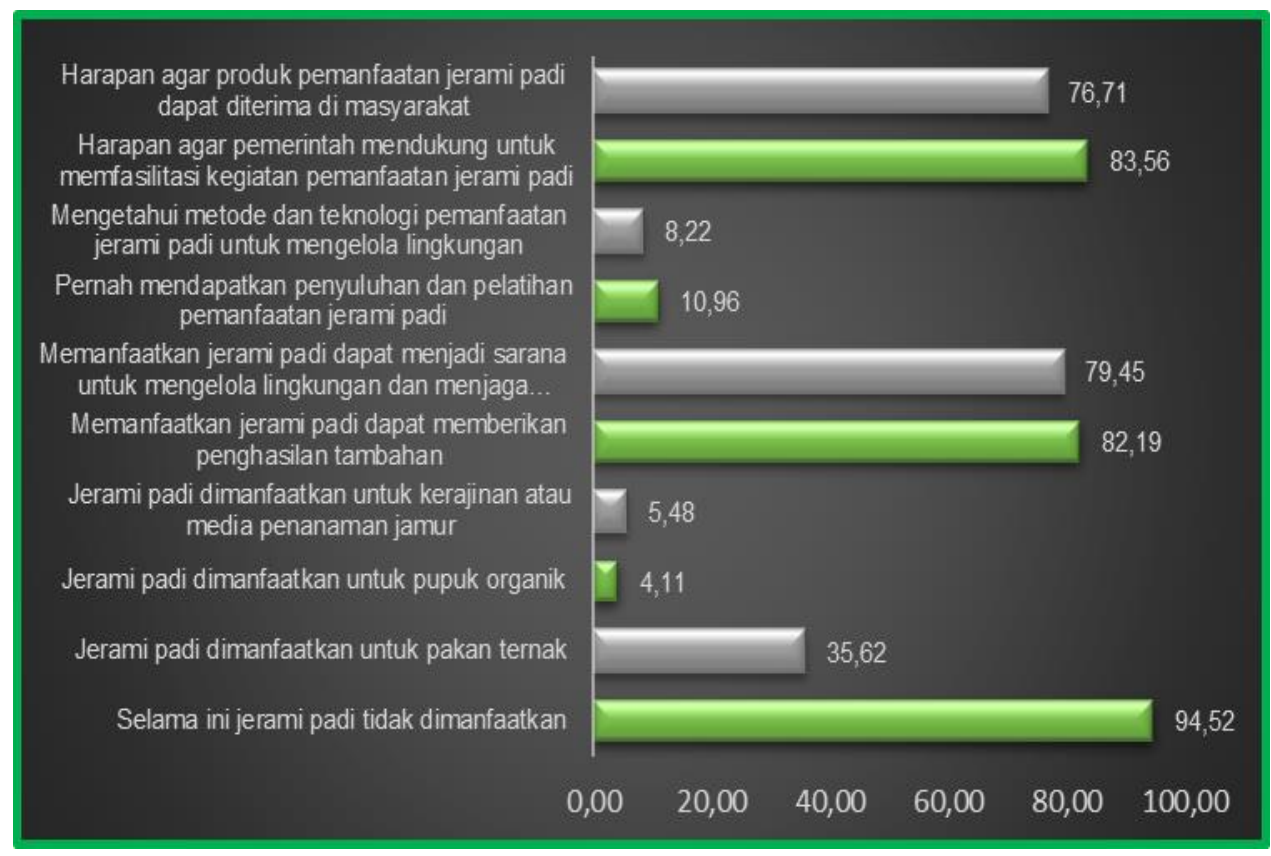

Gambar 6. Data hasil persepsi responden tentang pemanfaatan jerami padi

\section{Pelatihan Pemanfaatan Jerami Padi}

Kegiatan pelatihan pemanfaatan jerami padi menjadi pupuk organik bagi anggota majelis taklim di Desa Garon dilakukan 3 (tiga) kali pertemuan dengan rincian kegiatan ditunjukkan Tabel 1.

Tabel 1. Rincian kegiatan pelatihan pemanfaatan jerami padi

\begin{tabular}{|c|c|c|c|c|}
\hline $\begin{array}{l}\text { Pelatih- } \\
\text { an ke- }\end{array}$ & $\begin{array}{l}\text { Deskripsi } \\
\text { kegiatan }\end{array}$ & Pelaksanaan & Target & Indikator \\
\hline 1 & $\begin{array}{l}\text { Sosialisasi } \\
\text { pemanfaata } \\
\mathrm{n} \text { jerami } \\
\text { padi } \\
\text { sebagai } \\
\text { pupuk } \\
\text { organik }\end{array}$ & $\begin{array}{l}\text { Minggu ke-3 } \\
\text { Juli } 2018\end{array}$ & $\begin{array}{l}\text { Memahami } \\
\text { pentingnya } \\
\text { pemanfaatan } \\
\text { jerami sebagai } \\
\text { pupuk organik } \\
\text { padi sebagai } \\
\text { bagian dari } \\
\text { pengelolaan }\end{array}$ & $\begin{array}{l}85 \% \text { responden } \\
\text { mengetahui dan } \\
\text { memahami } \\
\text { pentingya } \\
\text { memanfaatkan } \\
\text { jerami padi } \\
\text { menjadi barang } \\
\text { berdaya guna dan }\end{array}$ \\
\hline
\end{tabular}




\begin{tabular}{|c|c|c|c|c|}
\hline & & & lingkungan & $\begin{array}{l}\text { upaya menjaga } \\
\text { keberlanjutan } \\
\text { lingkungan }\end{array}$ \\
\hline 2 & $\begin{array}{l}\text { Pembuatan } \\
\text { pupuk } \\
\text { organik } \\
\text { jerami padi }\end{array}$ & $\begin{array}{l}\text { Minggu ke-4 } \\
\text { Juli } 2018\end{array}$ & $\begin{array}{l}\text { Memahami } \\
\text { metode } \\
\text { pembuatan } \\
\text { pupuk organik } \\
\text { jerami padi }\end{array}$ & $\begin{array}{l}80 \% \text { responden } \\
\text { mampu membuat } \\
\text { pupuk organik } \\
\text { jerami padi }\end{array}$ \\
\hline 3 & $\begin{array}{l}\text { Pembuatan } \\
\text { pupuk } \\
\text { organik } \\
\text { jerami padi }\end{array}$ & $\begin{array}{l}\text { Minggu ke-2 } \\
\text { Agustus } \\
2018\end{array}$ & $\begin{array}{l}\text { Mengimplement } \\
\text { asikan pupuk } \\
\text { organik jerami } \\
\text { padi }\end{array}$ & $\begin{array}{l}80 \% \text { responden } \\
\text { mampu } \\
\text { mengimplementa } \\
\text { sikan pupuk } \\
\text { organik jerami } \\
\text { padi di lahan } \\
\text { pertanian }\end{array}$ \\
\hline
\end{tabular}
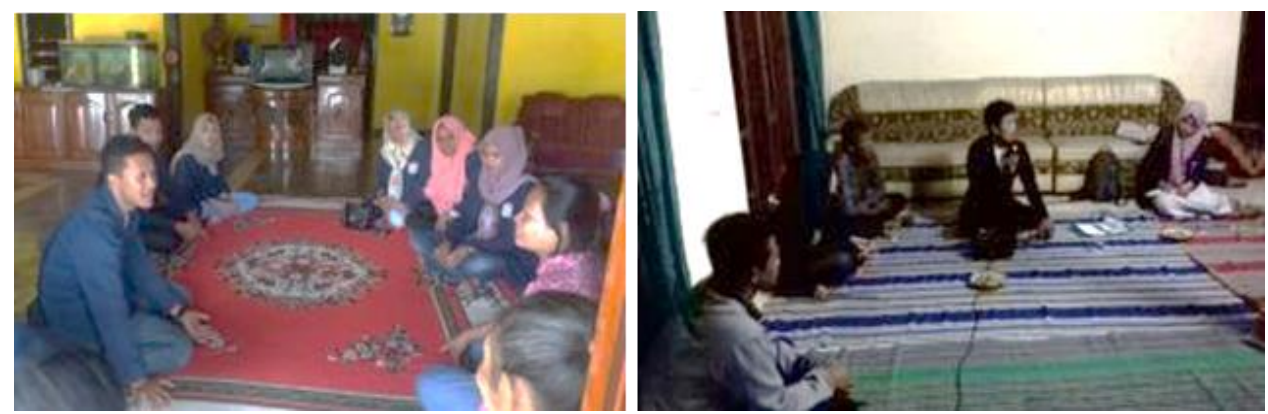

Gambar 7. Kegiatan sosialisasi pemanfaatan jerami padi (21 Juli 2018)

Proses pembuatan pupuk organik dari jerami padi yang harus diperhatikan adalah kondisi lingkungan dan cuaca. Apabila kondisi cuaca kemarau (panas) pembuatan pupuk organik jerami padi harus dilakukan didalam lubang dengan tujuan untuk mengurangi penguapan dan meminimalisir berkurangnya unsur $\mathrm{N}$. Tahapan pembuatan pupuk organik jerami padi dapat dilihat dari Gambar 8. 


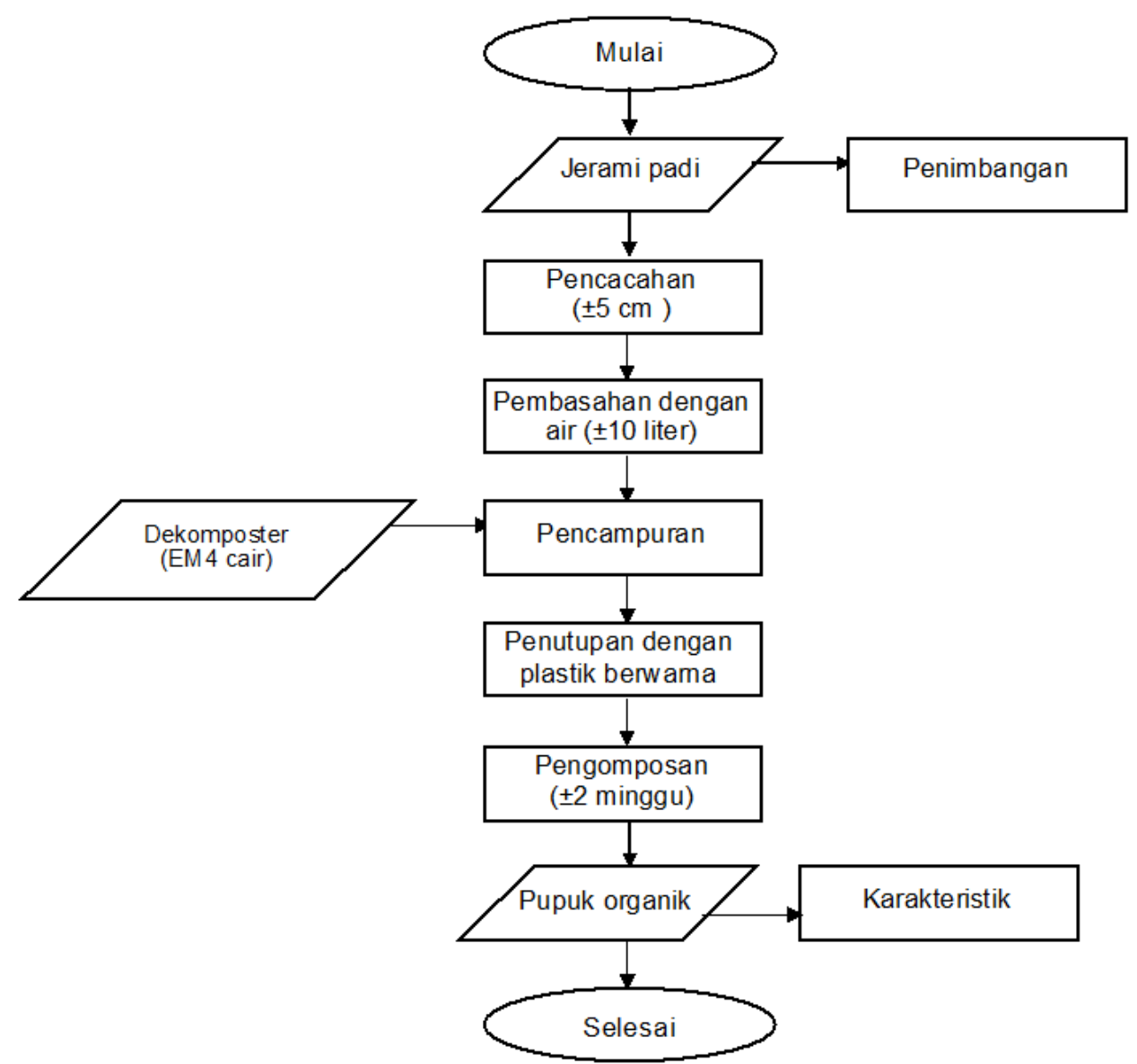

Gambar 8. Tahapan pembuatan pupuk organik jerami padi

(Hasil Penelitian Pendahuluan, 2018)

\section{KESIMPULAN}

Kegiatan pemanfaatan jerami padi di Desa Garon terselenggara sesuai dengan perencanaan yang telah disusun. Majelis taklim sebagai pilot model bukan hanya digunakan untuk kegiatan keagamaan tetapi juga sarana pemberdayaan masyarakat. Lebih dari $90 \%$ anggota majelis taklim tidak memanfaatkan jerami padi menjadi pupuk organk, pakan ternak, media penanaman jamur dan bioenergi. Jerami padi sebagai limbah hanya ditinggalkan di areal persawahan dan dibakar. Hal ini dikarenakan hanya 8-10\% anggota majelis taklim yang pernah mengikuti kegiatan penyuluhan dan pelatihan pemanfaatan jerami padi. Sehingga kegiatan pelatihan harus dilakukan untuk meningkatkan pemahaman dan pengetahuan anggota majelis taklim. Diharapkan melalui pemanfaatan jerami padi ini dapat dijadikan sebagai upaya pengelolaan lingkungan secara berkelanjutan. 


\section{DAFTAR RUJUKAN}

Andini, A., Bonnet, S., Rousset, P., \& Hasanudin, U. (2018). Impact of open burning of crop residues on air pollution and climate change in Indonesia. Current Science, 115(12), 2259-2266.

Gadde, B., Bonnet, S., Menke, C., \& Garivait, S. (2009). Air pollutant emissions from rice straw open field burning in India, Thailand and the Philippines. Environmental Pollution, 157(5), 1554-1558.

John, A. (2013). Alternatives To Open-Field Burning On Paddy Farms. OPTIONS Agricultural and Food Policy Studies Institute, Malaysia, 18, $1-5$.

Junpen, A., Pansuk, J., Kamnoet, O., Cheewaphongphan, P., \& Garivait, S. (2018). Emission of Air Pollutants from Rice Residue Open Burning in Thailand, 2018. Atmosphere, 9(11), 1-23.

Kanokkanjana, K., \& Garivait, S. (2013). Alternative rice straw management practices to reduce field open burning in Thailand. nternational Journal of Environmental Science and Developmen, 4(2), 119-123.

Lim, J. S., Manan, Z. A., Wan Alwi, S. R., \& Hashim, H. (2012). A Review On Utilisation Of Biomass From Rice Industry As A Source Of Renewable Energy. Renewable and Sustainable Energy Reviews, 16, 3084-3094.

M. Z, R., B, A., \& Aznie C.R, R. (2012). Impact of Rice Straw Development towards Agricultural Environment and Farmers' Socio-Economy in MADA Region, Kedah (Vol. 54, pp. 245-249). Presented at the 2nd International Conference on History and Society Development (ICHSD, Bangkok, Thailand: International Economics Development Research Center (IEDRC).

Mandal, K. G., Misra, A. K., Hati, K. M., Bandyopadhyay, K. K., Ghosh, P. K., \& Mohanty, M. (2004). Rice residue-management options and effects on soil properties and crop productivity. Food, Agriculture \& Environment, 2(1), 224-231.

Muliarta, I. N. (2018). Utilization Burning Rice Straw And Crops Planted. International Journal of Life Sciences, 2(3), 142-150.

Rhofita, E. I. (2016). Kajian Pemanfaatan Limbah Jerami Padi di Bagian Hulu. Al-Ard: Jurnal Teknik Lingkungan, 1(2), 74-79.

Tung, N. S., Cu, N. X., \& Hai, N. X. (2014). Impact Of Rice Straw Burning Methods On Soil Temperature And Microorganism Distribution In The Paddy Soil Ecosystems. ARPN Journal of Agricultural and Biological Science, 9(5), 157-160. 